\title{
The Impact of Relevant Costing for decision-making in Ready- Made Garments (RMGs) industry of Bangladesh.
}

\author{
Mohammad Mazibar Rahman ${ }^{1}$, Saiful Islam ${ }^{2}$ \\ ${ }^{1}$ (Department of Accounting, Hajee Mohammad Danesh Science and Technology University, Bangladesh. \\ ${ }^{2}$ (Lecturer, Department of Accounting, Hajee Mohammad Danesh Science and Technology University, \\ Bangladesh.
}

\begin{abstract}
Relevant costing is a management accounting term that relates to focus on only the cost relevant to a specific decision being made. Irrelevant costs are excluded from any incremental decision-making problem because they are supposed to have equal effects on all the available alternatives (Dillon, R. D. and, J. F. Nash, 1978). This study adopts an observation of quantitative method with primary and secondary data in view of the nature of the analysis. Relevant costing is often used in short-term decision-making and a number of specific practical examples are illustrated in this study. This study has designed to make the aim of assessing the level of perceptions of four areas such as (i) making and buying; (ii) dropping or retaining a segment; (iii) constrained resources; and (iv) special orders; in using relevant costing in Ready-Made Garments (RMGs) industry of Bangladesh. To meet this aim total 100 companies as a sample from Ready-Made Garments (RMGs) industry have been randomly selected. By using variance analysis, authors have found that all four factors have significant influence in using relevant costing. Last, the result of this study suggested that the strengthening the decision-making mechanism required a strong relevant costing benefits and its proper application.
\end{abstract}

Keywords: Relevant costing, Constrained Resources, and Ready-Made Garments (RMGs) Industry etc.

\section{Introduction:}

The RMGs industry has become Bangladesh's key export industry and a main source of foreign exchange for the last 25 years. As a result of an insulated market guaranteed by Multi-Fibre Agreement (MFA) of General Agreement Tariff and Trade (GATT) and supportive policies of the Government of Bangladesh $(\mathrm{GoB})$, it attained a high profile in terms of foreign exchange earnings, exports, industrialization and contribution to the GDP within a short period. In less than a decade Government increased it exports, foreign exchange earnings, and contribution to the GDP by $4.39 \%$. RMGs exports reached a steadfast figure of USD 17.91 billion in fiscal year 2010-2011; accounting more than 78\% of national export earnings, which was about 4\%-5\% of the global total of such exports. It further contributes 10\% to the country GDP (Mahmud R.B., 2012). The foreign exchange earnings and employment generation of the RMGs sector have been increasing at doubledigit rates from year to year (Quddus, Rashid \& Mainuddin, 2000). Currently, there are more than 4,000 RMGs company in Bangladesh. More than 95 per cent of those firms are locally owned with the exception of a few foreign firms located in export processing zones (Gonzales, 2002).

Management oriented accounting should be able to oversee the successful implementation of decisions, from which are shown the true values which are compared with standard values (Mihaela Tulvinschi, 2010). Relevant costs and revenues as those future costs and revenues that will be changed by a decision, whereas irrelevant costs and revenues are those that will be not affected by a decision (Drury, 2004). Any cost would be an asset if it has a favorable economic effect on expected future costs or future revenues. In other words, if a given cost represents a future economic benefit in the iota of a reduction of total expected future costs treat addition to total expected future revenue in the ordinary course of business it is a relevant cost and should be considered unexpired (Fess P.E., 1963). If the costs increase, decrease, appear and disappear as different alternatives are concerned, it is a relevant cost (Lal, 2005). In case of relevant cost concepts, one is to compare relevant revenues with relevant cost and ignore historic sunk and past cost, from the decision-making process so that decision can be protected from being mislead.

\subsection{LITERATURE REVIEW:}

Relevant costs are future cash flows arising as a direct consequence of the decision under consideration. In many short-term situations, the fixed costs remain constant for each of the alternatives being considered and thus the marginal costing approach showing sales, marginal cost and contribution is particularly appropriate. In the long run (and sometimes in the short run) fixed costs do change and accordingly the differential costs must include any changes in the amount of fixed costs (Schweikart J. A., 1986). 
Making the decision is often a difficult task that is complicated by numerous alternatives and massive amounts of data, only some of which may be relevant (Victoravich L. M., 2010). Relevant cost is a cost whose magnitude will be affected by a decision being made. Management should consider only future costs and revenues that will differ under each alternative (Arora, 2008). Relevant information is the predicted future costs and revenues that will differ among the alternatives relevant information (Horngren, et al, 2006).

Each decision involves choosing from between two alternatives. In making a decision, the cost and benefits of one alternative must be compared to the costs and benefits of other alternatives. Costs that differ between alternatives are relevant costs. Distinguishing between relevant and irrelevant cost and benefits is critical for two reasons: First, irrelevant data can be ignored - saving decision makers tremendous amount of time and effort. Second, bad decisions can easily result from erroneously including irrelevant cost and benefits when analyzing alternatives (Garrison \& Noreen, 2012).

When choosing among different alternatives, the manager should concentrate only on the costs and revenues that differ across the decision alternatives; these are relevant cost/revenues. Whether particular costs and revenues are relevant for decision making depends on decision context and the alternatives available (Atkinson, et al, 2008). Relevant cost should be used for assessing the economic and financial consequences of any decision by management. Only relevant cost and benefits should be taken into consideration when evaluating the financial consequences of a decision (Emile Woolf, 2011).

Therefore, the study shows that how relevant costing and benefit play a significant role in decision making for a Ready-made GarmentsIndustry in Bangladesh.

\subsection{OBJECTIVES OF THE STUDY:}

The objectives of this study are as follows:

- To show the application of relevant costing terms in decision-making.

- To show the impact of relevant costing for decision-making in Ready-made Garments Industry (RMG) of Bangladesh.

\section{Methodology Of The Study:}

Data collection and sample: This study is mainly based on the both primary and secondary data. A structured survey questionnaire has been used for primary data collection. Sample size total 100 respondents company have been selected from BGMEA database and surveyed on a random sampling basis. Interviewed to get the answers of the questionnaires to one employee from each company such as General Manager, Assistant Manager, Cost \& Management Accountant (CMA) or others industry employees \& specialist. In the questionnaire the perception has been calculated by 5 point Likert type measurement scale where $5=$ Strongly Agree and 1= Strongly Disagree. Secondary sources are from different local and international published articles, books, websites, and seminar papers etc.

Data analysis: Data have been analyzed by using Mean value and Two-way ANOVA test. Significance level is $5 \%$.

Study period: Time of the study was November 2013 to Janurary, 2014.

\section{Applicability of Relevant Cost Concepts:}

\subsection{Making or Buying decision: (Harper College Tutorial, 2010)}

For many years PINAKI GARMENTS LTD. Company has purchased the starters that it is installed in its standard line of sweing machine. Due to a reduction in output, the company has idle capacity that could be used to produce the starters. The chief engineer has recommended against this moves, however, pointing out that the cost to produce the starters would be greater than the current $\$ 10.00$ per unit purchase price. The company's unit product cost, based on a production level of 60,000 starters per year, is as follows:

\begin{tabular}{|c|c|c|}
\hline Particular & Make & \\
\hline Direct materials & $\$ 4.00$ & \\
\hline Direct labor & 2.75 & \\
\hline Variable manufacturing overhead & .50 & \\
\hline Fixed manufacturing overhead, traceable & 3.00 & $\$ 180,000$ \\
\hline Fixed manufacturing overhead, common (allocated based on direct labor hours) & 2.25 & $\$ 135,000$ \\
\hline Total production cost & $\$ 12.50$ & \\
\hline
\end{tabular}


An outside supplier has offered to supply the starter to PINAKI or only $\$ 10.00$ per starter. One-third of the traceable fixed manufacturing costs represent supervisory salaries and other costs that can be eliminated of the starters are purchased. The other two-third of the traceable fixed manufacturing costs are a depreciation of special manufacturing equipment that has no resale value. The decision would have no effect on the common fixed costs of the company and the space being used to produce the parts would otherwise be idle.

\section{Decision:}

\begin{tabular}{|l|c|c|}
\hline \multicolumn{1}{|c|}{ Particulars } & \multicolumn{2}{c|}{ Relevant Costs } \\
\cline { 2 - 3 } & Make & Buy \\
\hline Direct materials & $\$ 4.00$ & \\
\hline Direct labor & 2.75 & .50 \\
\hline Variable manufacturing overhead & 1.00 & \\
\hline Fixed manufacturing overhead, traceable & & $\$ 10.00$ \\
\hline Purchase price & $\$ 8.25$ & $\$ 10.00$ \\
\hline Total relevant cost & 60,000 & 60,000 \\
\hline Units produced & $\$ 495,000$ & $\$ 600,000$ \\
\hline Total Cost & & \\
\hline
\end{tabular}

The two-third of the traceable fixed manufacturing overhead costs that cannot be eliminated, and all of the common fixed manufacturing overhead costs, are irrelevants. The company would save $\$ 105,000$ per year by continuing to make the parts itself. In other words, profits would decline by $\$ 105,000$ per year if the parts were purchased from the outside supplier.

3.2 Dropping or Retaining a Segment: (Harper College Tutorial, 2010)

Another area in which Relevant Costing is used is whether to drop a division or product. Companies often prepare income statements for their divisions or products. H.R. FASHION, a fabrics company has two departments, $\mathrm{X}$ and $\mathrm{Y}$. A recent monthly contribution format income state of the company follows.

\begin{tabular}{|c|c|c|c|}
\hline Particulars & $\mathbf{X}$ & $\mathbf{Y}$ & Total \\
\hline Sales & $\$ 3,000,000$ & $\$ 1,000,000$ & $\$ 4,000,000$ \\
\hline Variable expenses & 900,000 & 400,000 & $1,300,000$ \\
\hline Contribution margin & $2,100,000$ & 600,000 & $2,700,000$ \\
\hline Fixed expenses & $\underline{1,400,000}$ & $\underline{800,000}$ & $\underline{2,200,000}$ \\
\hline Operating income (loss) & $\$ 700,000$ & $(\$ 200,000)$ & $\$ 500,000$ \\
\hline
\end{tabular}

The study indicates that $\$ 340,000$ of the fixed expenses being charged to $\mathrm{Y}$ are sunk costs or allocated costs that will continue even if $\mathrm{Y}$ is dropped. In addition, the elimination of $\mathrm{Y}$ will result in a $10 \%$ decrease in the sales of $\mathrm{X}$.

\section{Decision:}

\begin{tabular}{|l|c|}
\hline \multicolumn{1}{|c|}{ Particulars } & Total \\
\hline Department Y contribution margin lost & $(\$ 600,000)$ \\
\hline Department X contribution margin lost & $\underline{(210,000)}$ \\
\hline \multicolumn{1}{|c|}{ Total contribution margin lost } & $(810,000)$ \\
\hline Avoidable fixed costs & 460,000 \\
\hline Decrease in operating income & $\underline{(\$ 350,000)}$ \\
\hline
\end{tabular}

Contribution margin lost if $\mathrm{Y}$ is dropped. Therefore, based on the data given, the $\mathrm{Y}$ segment should not be discontinued unless a more profitable use can be found. 
3.3 Special Orders: (Harper College Tutorial, 2010)

Special Orders are a classic area in which Relevant Costing is used. The customer is in an area that your business does not normally serve. The potential customer offers to buy your product or service at a price below the cost to provide the product or service (The special order).

A-Z KNITWEARS LTD. produces a single product. The cost of producing and selling a single unit of this product at the company's normal activity level of 8,000 units per year is:

\begin{tabular}{|l|c|}
\hline \multicolumn{1}{|c|}{ Particulars } & Total \\
\hline Direct materials & $\$ 2.50$ \\
\hline Direct labor & 3.00 \\
\hline Variable manufacturing overhead & .50 \\
\hline Fixed manufacturing overhead & 4.25 \\
\hline Variable selling and administrative expense & 1.50 \\
\hline Fixed selling and administrative expense & 2.00 \\
\hline
\end{tabular}

The normal selling price is $\$ 15.00$ per unit. The company's capacity is 10,000 units per month. An order has been received from an overseas source for 2,000 units at the special price of $\$ 12.00$ per unit. This order would not affect regular sales. If the order is accepted, how much will monthly profits increase or decrease? (The order will not change the company's total fixed costs.)

\section{Decision:}

\begin{tabular}{|l|c|c|}
\hline \multicolumn{1}{|c|}{ Particulars } & Amount & Total \\
\hline Selling price & & $\$ 12.00$ \\
\hline Direct materials & $\$ 2.50$ & \\
\hline Direct labor & 3.00 & \\
\hline Variable manufacturing overhead & .50 & \\
\hline Variable selling and administrative expense & $\underline{1.50}$ & \\
\hline Total variable expenses & & $\underline{7.50}$ \\
\hline Contribution margin & 4.50 & \\
\hline Units sold & & $\underline{2,000}$ \\
\hline Total contribution margin & & $\$ \underline{9.000}$ \\
\hline
\end{tabular}

The relevant cost is $\$ 1.50$ (the variable selling and administrative costs). All other variable costs are sunk, since the units have already been produced. The fixed costs would not be relevant, since they will not be affected by the sale of leftover units.

\subsection{Constrained Resources: (Harper College Tutorial, 2010)}

Relevant Costing is also very useful when deciding whether you should outsource a product. In these problems, you can either make an item that you use in your business or you can purchase it from an outside supplier. Peoples Fashion LTD. produces three products, X, Y, and Z. Data regarding the three products is as follows:

\begin{tabular}{|l|c|c|c|}
\hline \multicolumn{1}{|c|}{ Particulars } & $\mathbf{X}$ & $\mathbf{Y}$ & $\mathbf{Z}$ \\
\hline Selling price & $\$ 80.00$ & $\$ 56.00$ & $\$ 70.00$ \\
\hline Variable expenses: & & & \\
\hline Direct materials & 24.00 & 15.00 & 9.00 \\
\hline Direct labor & 14.00 & 13.00 & 15.00 \\
\hline Other variable expenses & 10.00 & 14.00 & 25.00 \\
\hline Contribution margin & $\$ 32.00$ & $\underline{\$ 14.00}$ & $\underline{\$ 21.00}$ \\
\hline
\end{tabular}

Demand for the company's products is very stronger, with far more order each month than the company can produce with the available raw materials. The same material is used in each product. The material cost $\$ 3$ per pound, with a maximum of 5,000 pounds available each month. In which order should the company produce X, $\mathrm{Y}$ and $\mathrm{Z}$ ? 


\section{Decision:}

\begin{tabular}{|l|c|c|c|}
\hline \multicolumn{1}{|c|}{ Particulars } & X & Y & Z \\
\hline Direct materials cost & $\$ 24.00$ & $\$ 15.00$ & $\underline{\$ 3.00}$ \\
\hline Cost per pound & $\underline{\$ 3.00}$ & $\underline{\$ 3.00}$ & 3.00 \\
\hline Direct material pounds per unit & 8.00 & 5.00 & $\underline{\$ 21.00}$ \\
\hline Contribution margin & $\underline{\$ 32.00}$ & $\underline{\$ 14.00}$ & $\underline{\underline{\$ 7.00}}$ \\
\hline Contribution margin per pound & $\underline{\$ 4.00}$ & $\underline{\$ 2.80}$ & \\
\hline
\end{tabular}

The company should accept orders first for $\mathrm{Z}$, second for $\mathrm{X}$ and third for $\mathrm{Y}$.

\section{Analysis And Discussion:}

To measure whether perception levels of four factors is same or not in Ready-Made Garments (RMGs) Industry, the authors have applied two-way ANOVA analysis using two hypotheses.

Hypothesis-1:

$H_{0}=$ There is no significant relationship between the relevant costing and decision making of Ready-made Garments Industry in Bangladesh.

$H_{A}=$ There is a significant relationship between them.

Hypothesis-2:

$H_{0}=$ The four levels of relevant costing factor are not equal for decision making inReady-made Garments Industry in Bangladesh.

$H_{A}=$ All the four levels are equal.

Table 1.1 : Mean value

\begin{tabular}{|l|c|c|c|c|c|c|}
\hline \multirow{2}{*}{ Relevant Costing Factor } & \multicolumn{7}{|c|}{ Total Respondent's points for Decision making } \\
\cline { 2 - 7 } & $\begin{array}{l}\text { Strongly } \\
\text { Agree }\end{array}$ & Agree & Undecided & Disagree & $\begin{array}{l}\text { Strongly } \\
\text { Disagree }\end{array}$ & Total \\
\hline Making \& buying & 350 & 100 & 12 & 2 & 0 & $=464$ \\
\hline $\begin{array}{l}\text { Dropping or retaining a } \\
\text { segment }\end{array}$ & 105 & 48 & 120 & 24 & 15 & $=312$ \\
\hline Constrained resources & 225 & 124 & 12 & 10 & 25 & $=396$ \\
\hline Special orders & 40 & 116 & 99 & 36 & 12 & $=303$ \\
\hline Total & 720 & 388 & 243 & 72 & 52 & $=\mathbf{1 4 7 5}$ \\
\hline
\end{tabular}

Correction Factor $=\frac{T^{2}}{N}$

$$
=\frac{(1475)^{2}}{20}=108781.25
$$

Sum of Square between decision making:

$$
\begin{aligned}
& =\frac{(720)^{2}}{4}+\frac{(388)^{2}}{4}+\frac{(243)^{2}}{4}+\frac{(72)^{2}}{4}+\frac{(52)^{2}}{4}-C . F \\
& =(129600+37636+14762.25+1296+676)-108781.25 \\
& =75189 \\
& V=(c-1)=(5-1)=4
\end{aligned}
$$

Sum of Square between Relevant Costing:

$$
\begin{aligned}
& =\frac{(464)^{2}}{5}+\frac{(312)^{2}}{5}+\frac{(396)^{2}}{5}+\frac{(303)^{2}}{5}-C . F \\
& =(43059.2+19468.8+31363.2+18361.8)-108781.25
\end{aligned}
$$




$$
\begin{gathered}
=3471.75 \\
\mathrm{~V}=(\mathrm{r}-1)=(4-1)=3
\end{gathered}
$$

Total Sum $=$

$$
\begin{aligned}
& (0)^{2}+(15)^{2}+(25)^{2}+(12)^{2}+(2)^{2}+(24)^{2}+(10)^{2}+(36)^{2}+(12)^{2}+(120)^{2}+(12)^{2}+(99)^{2}+ \\
& (100)^{2}+(48)^{2}+(124)^{2}+(116)^{2}+(350)^{2}+(105)^{2}+(225)^{2}+(40)^{2}-\text { C.F }
\end{aligned}
$$

$$
=(254,345-108,781.25)
$$

$=145,563.75$

Residual value $=(145,563.75-75,189-3,471.75)$

$$
\begin{gathered}
=66,903 \\
\mathrm{~V}=(\mathrm{c}-1)(\mathrm{r}-1) \\
=4 * 3=12
\end{gathered}
$$

Table 1.2: ANOVA Analysis

\begin{tabular}{|l|c|c|c|c|c|}
\hline Source of Variation & S.S. & d.f. & Mean Square & $\begin{array}{c}\text { Fevel of Sig. } \\
5 \%\end{array}$ \\
\hline Between decision making & 75,189 & 4 & $18,797.25$ & 3.38 & 3.26 \\
\hline Between Relevant costing & $3,471.75$ & 3 & $1,157.25$ & 0.22 & 3.49 \\
\hline Residual & 66,903 & 12 & $5,575.25$ & & \\
\hline Total & 145563.75 & 19 & & & \\
\hline
\end{tabular}

The above table shows that the relationship between the relevant costing and decision making of Ready-made Garments (RMGs) Industry in Bangladesh vary due to the calculated value 3.38 and the table value for F $(4,12)$ is 3.26. On the other hand, the using relevant costing in respect of four factors in decision making are not same. The calculated value between relevant costing is 0.22 , but the table value for $\mathrm{F}(3,12)$ at the $5 \%$ level of significance $=3.49$.

\section{Conclusion:}

Relevant costing provide a very useful way of assessing whether company that shows a loss at the net marginal level are nevertheless viable in the short-term. Consumers are more and more demanding, looking for everything at a very attractive price. The company has to master revenues and costs very carefully to make a profit (Kaplan, 1990). The relevant costing will vary with each company according to circumstances. In our analysis for hypothesis test one, we reject the null hypothesis and accept the alternative which shows that there is a significant relationship between the relevant costing and decision making of RMGs in Bangladesh. But in test two we reject alternative and accept null hypothesis because of the result means the decision regarding the four levels of relevant costing varies. Everything in this study consists of application of one simple, but powerful idea. This simple idea was applied in a variety of situations including decisions that involve adding or dropping a product line, making or buying a component, accepting or rejecting a special order, using a constrained resource in RMGs in Bangladesh. Indeed, any decision involving costs hinges on the proper identification and analysis of the costs that are relevant. Consequently, relevant costing is an important concept in Managerial accounting which clearly depicts in this study about successful decision making in RMGs in Bangladesh.

\section{References:}

[1]. Arora, M.N. (2008). Cost Accounting. ( $3^{\text {rd }}$ edition) Noida: Vikas Publication House.

[2]. Atkinson, Anthony A., Kaplan Robert S., Young Mark S. (2008). Management Accounting.(6th Edition). New Delhi: Prentice Hall of India.

[3]. Dillon, R. D. and J. F. Nash. (1978). The true relevance of relevant costs. The Accounting Review, Vol. 53, No. 1: pp 11-17.

[4]. Drury, C. (2004).Management and cost accounting, (6th Edition). Thomson, London.

[5]. Emile Woolf (2011). Performance Management. (2 ${ }^{\text {nd }}$ edition). Berkshire: Emile Woolf Publishing Company. (Chapter- 7), pp: 129139.

[6]. Fess, P. E. (1963). The relevant costing concept for income measurement - Can it be defended? The Accounting Review (October): pp 723-732.

[7]. Garrison, Noreen and Brewer (2012). Managerial accounting. (13 ${ }^{\text {th }}$ edition).MaGraw-Hill International Publication. (Chapter- 13)

[8]. Gonzales, Aimee (2002). Sustainable Trade in Textiles and Clothing, dialogue report from the Expert Panel on Trade and Sustainable Development (Gland, Switzerland, World Wide Fund for Nature (formerly World Wildlife Fund). 
[9]. Harper College Tutorial, (2010): Relevent costing for decision making, Ch-11, pp 1-19. Retrived on Janurary, 2014. http://dept.harpercollege.edu/tutoring/pdfs/ac102_ch11.pdf

[10]. Horngren, Charles T., Sedan, G.L., Stratton (2006). Introduction to Management Accounting. (13 edition). New Delhi: Prentice Hall of India.(Chapter-11).

[11]. Kaplan, R.S.(1990), 'The Four-Stage Model of Cost Systems Design',Management Accounting, February, pp.22-26.

[12]. Lal, Jawahar (2005). Managerial Accounting. ( $3^{\text {rd }}$ edition), Delhi: Himalay Publication House.

[13]. Mahmud R.B (2012 ) Skills development in Bangladesh RMG sector, the News Today, http://www.newstoday.com.bd

[14]. MihaelaTulvinschi, (2010). Relevant Costs for Decision in an Effective Controlling System. Theoretical and Applied Economics Volume XVII (2010), No. 5(546), pp. 49-58.

[15]. Quddus, Rashid \&Mainuddin (2000) Databases of the Bangladesh Garment Manufacturers and Exporters Association, Export Promotion Bureau of Bangladesh and World Trade Organization: Pp 214-461.

[16]. Schweikart, J. A. (1986). The relevance of managerial accounting information: A multinational analysis. Accounting, Organizations and Society 11(6): 541-554.

[17]. Victoravich, L. M. (2010) When do opportunity costs count? The impact of vagueness, project completion stage, and management accounting experience. Behavioral Research In Accounting 22(1): pp 85-108.

[18]. http://www.bgmea.com.bd/

\section{APPENDIX}

\section{A. TOTAL RESPONDANT $=100$.}

\begin{tabular}{|l|l|l|l|l|l|}
\hline \multirow{2}{*}{$\begin{array}{c}\text { Relevant Costing } \\
\text { Factor }\end{array}$} & $\begin{array}{l}\text { Strongly } \\
\text { Agree }\end{array}$ & Agree & Undecided & Disagree & Strongly Disagree \\
\hline Making \& buying & 70 & 25 & 4 & 1 & 0 \\
\hline $\begin{array}{l}\text { Dropping or } \\
\text { retaining a segment }\end{array}$ & 21 & 12 & 40 & 12 & 15 \\
\hline $\begin{array}{l}\text { Constrained } \\
\text { resources }\end{array}$ & 45 & 31 & 4 & 5 & 25 \\
\hline Special orders & 8 & 29 & 33 & 18 & 12 \\
\hline
\end{tabular}

\section{B. LIKERT TYPE MEASUREMENT SCALE:}

Strongly Agree $=5$ points

Strongly $=\quad 4$ points

Undecided $=3$ points

Disagree $=2$ points

Strongly Disagree $=1$ points

\begin{tabular}{|l|c|c|c|c|c|}
\hline \multirow{2}{*}{ Relevant Costing Factor } & \multicolumn{5}{|c|}{ Total Respondent's points for Decision making } \\
\cline { 2 - 6 } & $\begin{array}{c}\text { Strongly } \\
\text { Agree (5) }\end{array}$ & Agree (4) & Undecided (3) & Disagree (2) & $\begin{array}{l}\text { Strongly } \\
\text { Disagree(1) }\end{array}$ \\
\hline Making \& buying & 350 & 100 & 12 & 2 & 0 \\
\hline $\begin{array}{l}\text { Dropping or retaining a } \\
\text { segment }\end{array}$ & 105 & 48 & 120 & 24 & 15 \\
\hline Constrained resources & 225 & 124 & 12 & 10 & 25 \\
\hline Special orders & 40 & 116 & 99 & 36 & 12 \\
\hline
\end{tabular}

